Discussion

Papers

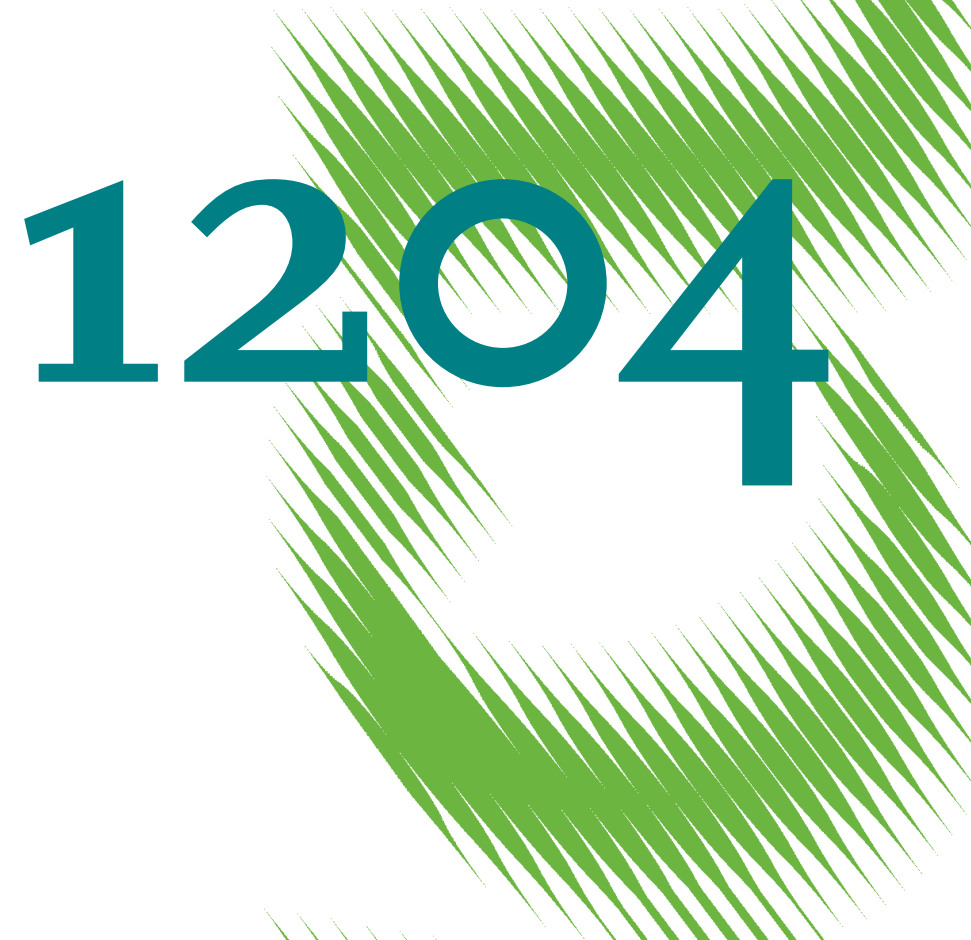

Does Fiscal Decentralization Foster Regional Investment in Productive Infrastructure? 
Opinions expressed in this paper are those of the author(s) and do not necessarily reflect views of the institute.

IMPRESSUM

(C) DIW Berlin, 2012

DIW Berlin

German Institute for Economic Research

Mohrenstr. 58

10117 Berlin

Tel. $+49(30) 89789-0$

Fax +49 (30) $89789-200$

http://www.diw.de

ISSN print edition $1433-0210$

ISSN electronic edition 1619-4535

Papers can be downloaded free of charge from the DIW Berlin website:

http://www.diw.de/discussionpapers

Discussion Papers of DIW Berlin are indexed in RePEc and SSRN:

http://ideas.repec.org/s/diw/diwwpp.html

http://www.ssrn.com/link/DIW-Berlin-German-Inst-Econ-Res.html 


\title{
Does fiscal decentralization foster regional investment in productive infrastructure?
}

\author{
Andreas Kappeler ${ }^{+}$, Albert Solé-Ollé ${ }^{\wedge}$ Andreas Stephan^ and Timo Välilä*
}

\begin{abstract}
:
The aim of this paper is to analyze the effect of revenue decentralization on the provision of infrastructure at the sub-national level. We estimate the effects of revenue decentralization and earmarked grant financing on the level of sub-national infrastructure investment in 20 European countries over the period 1990-2009. The results are interpreted in light of the predictions of the theory on fiscal federalism. We find that it is sub-national infrastructure investment that increases after revenue decentralization and not investment in redistribution. However, the effect of revenue decentralization is lower the higher the use of earmarked grants to fund infrastructure investment.
\end{abstract}

Keywords: Regional investment, fiscal federalism, dynamic panel data

JEL Codes: H54, H77, H76, C23

Disclaimer: Opinions expressed in this paper are those of the authors. They do not necessarily reflect the views of the institute or the EIB.

${ }^{+}$Economics Department, European Investment Bank, 100, boulevard Konrad Adenauer, L-2950 Luxembourg e-mail: a.kappeler@eib.org

${ }^{\Delta}$ Faculty of Economics, University of Barcelona, e-mail: asole@ub.edu

`Jönköping International Business School, Jönköping University, e-mail:

Andreas.Stephan@jibs.hj.se

*Economics Department, European Investment Bank, e-mail: t.valila@eib.org 



\section{Introduction}

Spending on productive infrastructure is seen as an important determinant of long term economic growth (see Romp and de Haan, 2005, and Bom and Ligthart, 2008, for recent surveys). Several authors have documented a downward trend in public investment during the last three decades (Välilä et al., 2005) and warned about its possible detrimental effects on the economy (see, e.g. Sturm et al., 1999). This debate has been important within the European Union, given the drawn-out fiscal consolidations in the past four decades and the associated downtrend in public investment. In many instances, it has been much easier to achieve the required fiscal consolidation by cutting investment than by reducing current spending and raising taxes (see, e.g., Mehrotra and Välilä, 2006).

A not well-realized fact is that productive infrastructure investment is mostly provided by sub-national governments. According to Estache and Sinha (1995) most infrastructure services where benefits are mostly local -as, e.g. road construction and maintenance, urban transit, water supply, and waste management- are completely decentralized in many countries and decentralization is proceeding rapidly in many others. Big infrastructures, as airports and ports, are also locally managed and funded in many countries (see, e.g. Bel and Fageda, 2009). The central government retains the responsibility over utility infrastructures, as telecommunications and power, but even in this case technological improvements are facilitating the transfer of responsibilities to sub-national governments ${ }^{1}$.

This is certainly the case in Europe, as Figure A.1 in the Annex clearly illustrates. The share of sub-national investment in economic infrastructures is $70 \%$ in EU-10 countries, around $60 \%$ in Cohesion countries, and more than $40 \%$ in the New Member

\footnotetext{
1 Although in these cases the most relevant policy responsibilities are regulatory, most investment being carried out by private actors (see Alegre et al., 2008, and Montolio and Trillas, 2011).
} 
States. The sub-national share of investment in Public Goods is of a similar size, while the sub-national share of investment in Hospitals and Schools and Redistribution is even higher. These numbers mean that what sub-national governments do is crucial for sustaining the level of investment and avoiding a depreciation of the capital stock. Of course, a considerable proportion of this investment is funded through capital grants, some of them funded by the national government and others coming from the EU.

Both scholars and international organizations recommend a decentralized approach to the provision of infrastructure (World Bank, 2001; Brosio and Ahmad, 2009). Better matching of preferences and needs (Oates, 1972; Faguet, 2004) and increased accountability (see, e.g. Seabright, 1996) are the arguments used to support this policy. Decentralization is typically recommended if the above benefits compensate for any inefficiency generated by spillovers and/or the limitation of economies of scale. In cases where spillovers and/or scale economies are important, sub-national provision coupled with national or even supra-national funding is recommended (see, e.g. Hulten and Schwab, 1997). Yet there are just a few papers that have analyzed the effectiveness and efficiency of these arrangements, as most of them focus on the ability of infrastructure investment to promote growth and convergence (García-Milà and McGuire, 1996; Puga, 1999).

There are just some papers in the literature analyzing how sub-national governments set their investment. For example, Holtz-Eakin and Schwartz (1995) document that investment by US local governments depend on the current level of revenues, resulting in a pro-cyclical behaviour. Sub-national fiscal adjustment also seems to fall disproportionally over investment in Spain, according to Solé-Ollé and Sorribas-Navarro (2011). These authors document a pattern of sub-national fiscal adjustment that has some differences to the one found for the cases of the US and Germany (see, Buettner and Wildasin, 2006, and Buettner, 2009, respectively). These 
authors suggest that the answer to these differences must lie in the institutional framework of local governments in each country.

An under-researched - but theoretically plausible - determinant of the composition of public investment at the sub-national level is the degree of fiscal decentralization. While the impact of expenditure decentralization is straight-forward, the impact of revenue decentralization on sub-national spending decisions is not well understood. Revenue decentralization has many dimensions (Stegarescu, 2005). In this paper we focus on two of them: (i) the percentage of revenues coming from taxes generated sub-nationally, and (ii) the use of transfers that are earmarked to specific purposes (here to infrastructure investment). Related to the first dimension, in countries where sub-national governments are mostly funded with intergovernmental transfers, the sub-national budget constraint is typically isolated from sub-national spending decisions. Although more spending on productive infrastructure could foster the growth of tax bases and tax revenues, sub-national revenues are generally insensitive to economic growth. Thus the incentives to pursue growth-enhancing policies (invest in productive infrastructure) are much lower than in countries where sub-national governments are funded through tax revenues. Surprisingly, there are no empirical papers studying whether the shift in incentives caused by tax decentralization is quantitatively meaningful. Previous work has shown that revenue decentralization has a significant positive impact on governments' aggregate investment in infrastructure (Kappeler and Välilä, 2008), although it has not been examined what level of government accounts for that increase.

However, the second dimension - the use of earmarked capital transfers- could potentially counteract the incentive effects provided by fiscal decentralization. The reason is that the use of earmarked transfers might considerably reduce the autonomy that sub-central governments have on decisions regarding amount and composition of 
investments. Selecting investment projects based on complex hierarchical systems might in practice delink the decision to undertake a project in a given region from its growth effects - and thus tax revenues - in that particular region. We are also not aware of any empirical contribution analyzing the effect on public investment of this interaction between fiscal decentralization and the funding through capital transfers.

The relationship between fiscal decentralization and the composition of public spending has been assessed empirically from a number of angles. Closest to our analysis is Kappeler and Välilä (2008), who consider the impact of different decentralization measures on four types of investment by the general government (i.e., aggregating the central and sub-national levels of government) in a panel of EU member states. They conclude that decentralization increases aggregate (general government) investment in infrastructure, schools and hospitals, and in public goods such as defence, environment and order and safety. They find no significant impact on redistributive capital outlays (social housing, recreation, social protection).

A number of empirical studies consider whether decentralization is associated with a higher degree of responsiveness to local preferences. Jin et al. (2005) find that in China an increase in tax revenue retention rate boosts regional governments' probusiness policies, leading e.g. to higher growth of rural enterprise employment and private non-agricultural employment. Esteller and Solé (2005) find that decentralization (task assignment) in Spain (at NUTS-3 level) increased the sensitivity of public investment in infrastructure and schools to regional output, users and costs. Finally, Faguet (2005) suggests that decentralization in Bolivia and Colombia made public investment more responsive to local needs. In Bolivia investment in education and sanitation rose where illiteracy was highest and sanitary connections poorest, respectively.

Studies focussing on German municipalities and counties have found support for fiscal competition increasing spending on public inputs. Hauptmeier et al. (2009), 
considering German local governments (municipalities in the state of BadenWürttemberg), conclude that they use both corporate tax (Gewerbesteuer) rates and public inputs (spending on municipal road network) to compete for mobile capital. If neighbours cut tax rates, local governments cut, too, and boost spending on public inputs. Borck et al. (2005) find that German counties (Landkreise) use spending to attract mobile capital and labour. This holds at the aggregate level of spending and individually for spending on general administration, schools, R\&D, housing and business development. There is no significant relationship for spending on public safety, health and recreation.

In sum, there is some empirical evidence suggesting that decentralization may cater better to local preferences and boost expenditure on public inputs, including through competition for capital and labour between sub-national units of government. The earlier empirical literature has left gaps to be filled. There is a paucity of systematic cross-country evidence, as the focus in the studies mentioned above has been mainly on individual countries. Also, very few studies have contrasted investment in public inputs (such as infrastructure) with other types of public spending (investment), thus not being able to detect any systematic differences between different types of sub-national spending (investment). As a result, it has so far not been possible to test the hypotheses derived.

The aim of this paper is to analyze the effect of revenue decentralization on the provision of infrastructure at the sub-national level. Does revenue decentralization, measured as the budget share of locally-generated tax revenues, provide incentives to spend (relatively) more on growth-enhancing infrastructure policies? Does the use of capital grants countervail or enhance the incentives provided by tax decentralization? We estimate the effects of revenue decentralization and earmarked grant financing on the level of sub-national infrastructure investment in 20 European countries over the 
period 1990-2009. We interpret the results in light of the predictions of the theory of fiscal federalism. The findings are compared to those obtained when using sub-national investment in redistribution, for which the theory predictions are different. Our results show that it is sub-national infrastructure investment that increases after revenue decentralization and that this does not occur with other types of investment. We also find that the effect of revenue decentralization is lower the higher the use of earmarked grants to fund infrastructure investment.

The paper is organized as follows. Section 2 reviews a number of theoretical approaches linking fiscal decentralization with the composition of government spending, seeking to articulate testable hypotheses for the subsequent empirical analysis. Section 3 presents the empirical strategy and data, and Section 4 reports and interprets the results. Section 5 concludes.

\section{Theoretical framework}

This section presents a brief overview of different theories of fiscal federalism with a focus on the impact of tax decentralization and earmarked transfers on the level and composition of government spending.

Fiscal interest theory. This line of reasoning (see, e.g. Weingast, 2009) suggests that tax decentralization, by explicitly connecting the effects of spending policies with the revenue budget, provides incentives to focus on growth-enhancing policies and to reduce rent-seeking and waste in government. In this second generation fiscal federalism theory, sub-national governments are considered to be pursuing their own interests rather than being benevolent (see also Oates, 2005). Financing through formula grants does not provide the adequate incentives to foster growth because the effect of a region's economic policies is translated to the growth of the national revenue pool, of 
which at most the region will be able to capture a tiny proportion. Careaga and Weingast (2003) call this effect the 'fiscal law of $1 / n$ ', obviously referring to the share of national revenues captured by one region when there are $n$ regions of same size. In contrast with this, entirely funding spending through taxes generated in the region means that $100 \%$ of the revenues generated as a result of a particular policy are kept in the revenue budget of the sub-national government.

The prediction of this theory is clear. Increasing tax decentralization would increase the \% of revenues retained by the region (the so-called 'marginal retention rate') and this will increase the marginal benefit of productive spending vis-a-vis other possible uses of spending. These authors focus on the effects of rents and wasteful spending (see Weingast, 2009, and Careaga and Weingast, 2003), meaning that tax decentralization would increase the efficiency in government spending and, under some conditions, even reduce the size of the overall budget. Note, however, that the stronger incentives to spend productively will also reduce other spending even if it can not be considered wasteful. But even in this case the effect would be efficiency-enhancing, since previous to tax decentralization the sub-national government was not considering the correct relative prices of the different types of spending. Note also that the argument does not depend on the mobility of tax bases, since the effects of productive spending on the tax base could simply occur through its effect on the growth of the national tax base. As pointed out by Hindriks et al. (2008), the fiscal interest theory does not make any explicit treatment of mobility.

Given the policy shift towards more productive spending and more growthoriented government policies, the Fiscal interest theory also suggest that growth should be stronger in tax-decentralized places. More concretely, the main hypothesis that has been put to test is the one that links the marginal retention rate (\% of taxes retained by sub-national governments / taxes generated sub-nationally) and the GDP growth rate. 
For example, Jin et al. (2005) and Zhuravskaya (2005) provide evidence of such a positive link for China and Russia, respectively, and Weingast (2009) discusses additional cases of study. To our knowledge, the link between fiscal incentives and subnational infrastructure policies has not been analyzed.

Fiscal competition. The literature on fiscal competition between sub-national units of government has generated a number of reasonably clear-cut insights about the composition of their spending. It is important to recognize that competition in this context is considered active in the sense that sub-national governments use tax or expenditure policies to pursue certain goals (such as to attract firms in order to boost their employment and income), with policy decisions by one unit affecting others (Ferreira et al., 2005).

In the simplest case the competition between sub-national governments (call them "regions" for simplicity) only concerns tax rates: each region seeks to attract productive firms by lowering tax rates on mobile capital. As firms move to regions with the lowest tax rates, a "race to bottom" ensues, resulting in sub-optimally low tax rates and, hence, sub-optimally low levels of tax revenues as well as spending by regions on both public consumption goods and public investment. This conclusion has been associated with Zodrow and Mieszkowski (1986). ${ }^{2}$

Extending the competition between regions to cover not only tax policies but also expenditure policies, Keen and Marchand (1997) conclude that the outcome is a relative overprovision of productivity-enhancing public inputs such as infrastructure (which attract mobile capital) and an under-provision of public consumption goods. The analysis of Keen and Marchand has been extended in Borck (2005). He introduces mobile skilled labour and immobile unskilled labour as extensions of the tax base,

\footnotetext{
${ }^{2}$ However, Sinn (2003) has argued that the analysis is methodologically flawed and that the conclusion only holds for public consumption goods.
} 
together with three public goods: a public input, a public consumption good benefiting skilled labour (e.g. “opera houses”) and unskilled labour (e.g. “social housing”), respectively. The mobility of capital and skilled labour in this set-up will lead to an overprovision of the public input as well as the public good benefiting skilled labour, and to an under-provision of the public good benefiting unskilled labour. More recently, Benassy-Quere et al. (2007) obtain the same results regarding the relative overprovision of infrastructure in a more general framework ${ }^{3}$.

Also in these models, tax decentralization (understood as a sub-national participation on the revenues generated in the jurisdiction) is the force behind the bias in favour of productive spending. In fact, some authors have suggested the use of (Pigouvian) grants to alleviate this bias (see, e.g. Ferreira et al., 2005, and Hindriks et al., 2008). In practice, these grants can take two forms: (i) matching grants earmarked to investment spending, and (ii) general equalization transfers, which can be used to fund any kind of spending ${ }^{4}$. In the margin, if a sub-national government has to share with the rest of the country a \% of the extra revenues generated by a particular growth enhancing infrastructure project, the marginal benefits of this project will be reduced. An increase in the \% of equalization is akin to a reduction in the percentage of taxes in the revenue budget of sub-national governments, both policies having thus the same effects.

Capital grants. In practice, public investment at sub-national level is funded in a non-deniable proportion by capital grants from national or even supra-national (the EU) governments. These grants are earmarked for capital spending and have co-funding

\footnotetext{
${ }^{3}$ We have to admit that the over-investment result if not universal. Recently Hindriks et al. (2008) have developed a dynamic model where sub-national governments invest in infrastructure in the first period in order to alleviate tax competition in the second one. This particular timing of the game generates under-investment. See also Bucovetsky (2005) for alternative analysis of the over vs under-provision of productive goods.

${ }^{4}$ See also Bucovetsky and Smart (2006) for analysis of the incentives effects of equalization transfers on tax-setting in a situation with tax competition. These authors do not consider the effect on the spending mix.
} 
requirements at the project level (i.e. the sub-national government has to provide a given per cent of the funding of each project). Which is the impact of these grants on the level of investment? It is tempting to answer that these grants are like the matching grants proposed above. However, this is probably not the case in practice. Since they are not open-ended, and there is a high degree of fungibility between investment projects, they work more as a block grant. If optimal investment in the presence of transfers is higher than the amount of the grant multiplied by $1+m$, where $m$ is the matching rate (resources added by the sub-national government over grants), then the effect of the grant will be like the one of any other increase in unconditional resources. If optimal investment is lower than this threshold then the effect of the transfer would be to raise investment until this threshold is reached. Moreover, it could be that the effective matching rate is much lower than the one established in the rules of the grants, due to an improper application of the rules (e.g. using grants from other layers of government to justify the additional level of sub-national investment required by the rules) or to corruption (e.g. using the same certificates of investment done to collect grant payments from different layers of government or collecting grants for public works not really done). It is interesting to note that empirical studies estimating the ability of this type of capital grants over investment find that these grants are fungible, with each euro of grants stimulating investment by less than one euro (see, e.g. Lago-Peñas, 2006).

The effect of earmarked capital transfers on the effect of tax decentralization on investment is less straightforward. In theory, if earmarked capital transfers are like lump-sum transfers (as we argued above), more tax decentralization would still improve the incentives in the margin to shift the budget towards economic investment. However, there are several reasons that suggest that this might not be the case in practice. First, earmarked capital transfers often imply that an increase in the capacity of the central government to intervene in the selection of investment projects, thus constraining the 
capacity of sub-central governments of deciding on the amount and type of investment pursued. Second, earmarked transfers imply that sub-central governments have cofunding requirements. This might exhaust its ability to channel current account savings to marginal investment projects, even if these projects are profitable in terms of additional revenues. Third, as a the prospects of the region depend more on the decisions taken at central level (amount of transfers received and conditions attached), the resources of the regional government might shift towards rent-seeking activities (lobbying the central government) and away from studying which is the best way to improve the local economy (see Weingast, 2009).

Summing up, the predictions of the Fiscal competition theory (at least of most of the models) are the same than those of the Fiscal interest literature: more tax decentralization (and/or less equalization) will generate more investment on productive infrastructure, relative to other types of investment. Of course, the normative implications are different. In the Fiscal competition literature, the situation before a possible reduction in tax decentralization is one of over-provision of infrastructure and, thus, reducing decentralization would bring the level of infrastructure provision closer to the social optimum. In the Fiscal interest literature the situation is reversed: with decentralization the optimal level of infrastructure would be provided, so centralization would move the level of provision towards an under-provision. In any case, both first and second generation theories predict more infrastructure investment as tax decentralization increases. We seek to test whether that is, indeed, true, and also how grants affect that relationship. 


\section{Econometric Approach}

\subsection{Model}

Our aim is to identify the impact of decentralisation on different types of regional (state+local) investment. For doing so, we compare 2 types of regional investment: (1) Economic affairs, which mainly consists of transport investment (see Alegre et al. (2008)) and (2) Redistribution (social protection, recreation, culture and religion and housing). Mapping the hypotheses outlined in Section 2, we specify an econometric model to measure the link between regional investment and decentralisation.

(1) $I_{i t}^{k}=\lambda I_{i t-1}^{k}+\beta_{1} T_{i t-1}+\beta_{2} G_{i t}+\beta_{3} T_{i t-1} \times G_{i t}+\beta_{4} G D P_{i t-1}+\beta_{5} D_{i t-1}+\beta_{6} S_{i t-1}+\gamma_{i}+\gamma_{t}+u_{i t}$

where $u_{i t} \sim$ i.i.d $\left(0, \sigma^{2}\right)$, with subscript i referring to observations in the cross-sectional dimension (individual countries) and to observations in the time dimension. The dependent variable $I_{i t}^{k}$ represents gross sub-national capital formation of type $k(k=1$, 2). Gross capital formation includes changes in inventories, which may create some undesired variation for our analysis; however, the breakdown between gross fixed capital formation and changes in inventories is not available. $I_{i t}^{k}$ is expressed relative to trend GDP in order to avoid the estimated coefficients just pick up the effect of cyclical co-movements in investment and tax revenues.

Fiscal decentralisation is measured by the share of tax revenue attributed to subnational levels of government (local and state governments), which is denoted $T_{i t-1}$. The regional tax share is lagged by one period to reflect the fact that investment decisions are most often taken one year before the investment takes place, and investment decisions are most likely based on knowledge about the revenue situation at that time. 
We also control for investment grants from the central government to sub-national levels of government $\left(G_{i t}\right)$; they are also measured relative to trend GDP and contemporaneous with investment as they finance investment the same year it is undertaken. Grants include "other capital transfers and investment grants” 5 received by local and state governments aggregated over all types of investment. Therefore, it is its composition or its conditionality that drives the effect of grants in equation (1). For instance, a positive impact of investment grants on infrastructure investment may imply that either a large amount of modestly effective grants or a small share of highly effective grants is provided conditional on investment. The model also contains the interaction term between $T_{i t-1}$ and $G_{i t}$. This term is added to the equation to test whether the impact of decentralisation on different investment types depends on the amount of investment grants received.

To control for the macro-economic environment, we include real GDP, which is expressed relative to trend population and lagged by one period. The short- and longer term fiscal environment is captured by the budget surplus of the sub-national governments $\left(S_{i t-1}\right)$ and debt of the general government $\left(D_{i t-1}\right)$. Data for debt are only available as aggregate over all tiers of government. Both variables are measured in relation to trend GDP and lagged by one period. A reason for using the one-period lags of the real GDP and fiscal variables is to address any bias arising from the possible joint determination of these explanatory variables and the dependent one. ${ }^{6}$

\footnotetext{
${ }^{5}$ According to ESA-95, other capital transfers "cover transfers other than investment grants and capital taxes, which do not themselves redistribute income but redistribute savings or wealth among the different sectors or sub-sectors of the economy or the rest of the world. "Investment grants" consist of capital transfers in cash or in kind made by governments or by the rest of the world to other resident or non-resident institutional units to finance all or part of the costs of fixed assets.

${ }^{6}$ Note that the significance of our results do not change if the dependent variables - grant, debt and lend - are expressed relative to nominal GDP instead of nominal trend GDP. Results are available upon request.
} 


\subsection{Description of the Sample}

Our data are from Eurostat and OECD and cover 20 EU-countries (NACE 1) over the period 1990-2009. Most of the variables that we use are reported by sub-sector of government. Based on ESA-95 we define regional expenditure as the sum of local and state governments. General government, defined in ESA-95 refers to the sum over local, state and central government as well as social funds. Since not all countries have backdated all relevant series to 1990, the panel is unbalanced.

Table A1 in the Annex shows the summary statistics for the variables used. Table A2 in the Annex reports the results of the Im, Pesaran, and Chin (Im et al., 1997) and Fisher (Maddala and $\mathrm{Wu}, 1997)$ unit root panel tests. Overall, the tests demonstrate that all variables are stationary. Table A3 in the Annex shows the correlation matrix for variables included in our model. Correlation among explanatory variables is mostly negligible. $^{7}$

\subsection{Estimation Method}

To account for the high auto-correlation in the dependent variable (see Table A4 in the Annex), we apply a dynamic panel data approach.

Our preferred estimation method is the Corrected Least Squares Dummy Variable (LSDVC) estimator, which has recently been discussed in the literature for estimating dynamic panel data models where the $\mathrm{T}$ and $\mathrm{N}$ dimensions are similar to ours. MonteCarlo studies show that LSDV has a relatively small variance compared to the IV and GMM dynamic panel estimators. Kiviet (1995) discusses how to correct the bias of LSDV. Monte-Carlo evidence shows that corrected LSDV often outperforms the IV and GMM estimators in terms of bias and root mean squared error (RMSE) and suggests to

\footnotetext{
${ }^{7}$ A more informative indicator of multicollinearity is the Variance Inflation Factor (VIF). VIFs larger than 10 are found for regtax, grant, gdp and debt. This indicates that multicollinearity might be an issue for our estimations, adversely affecting the precision of the parameter estimates. Having said this, it would not affect the validity of our presented statistical inference.
} 
use LSDVC for data with a small N dimension (see e.g. Judson and Owen (1999)). Bruno (2005) extends the bias approximations derived in Bun and Kiviet (2003) to accommodate unbalanced panels with a strictly exogenous selection rule (LSDVC). Starting values for the bias correction with this methodology can be determined by either an Anderson-Hsiao (AH) estimator, the standard one-step Arellano-Bond (1991) estimator with no intercept, or the system GMM estimator that was implemented in STATA by David Roodman.

As the implementation of investment plans may take place over more than a year, one may argue that the share of tax revenue - even if lagged by one period - and government grants in Equation (1) may be correlated with the error term. This endogeneity would question the choice of LSDVC as preferred estimation method, which rests on the assumption of strict exogeneity of all regressors. Soto (2010) suggests that both fixed effects and GMM estimation results should be provided for small panels with a large number of $\mathrm{T}$ and a small number of $\mathrm{N}$. His Monte Carlo simulations suggest that the system GMM estimator has a relatively low bias in such cases. In contrast the OLS estimator has a lower variance but is characterized by a larger bias. Having said this, consistency of Arellano-Bond based GMM estimators is generally a problem for small $\mathrm{N}$ and large $\mathrm{T}$. In this case, the set of instruments is likely to eat up most of the degrees of freedom. Restricting the set of instruments, as suggested by Soto (2010) introduces a considerable degree of arbitrariness as parameter estimates and diagnostic test results may depend considerably on the choice of the set of instruments. Moreover, Primo et al. (2006) suggest that robust system GMM should only be applied if $\mathrm{N}$ is larger 50 . This limits the reliability of system GMM in cases like ours $(\mathrm{N}=20)$ and prevents the application of the Hansen test. For these reasons we prefer to present the fixed effects model and system GMM results only as robustness checks. 


\section{Results}

Below we present the results estimated with LSDVC for the empirical model represented by Equation (1) with the lagged dependent variable included to account for the dynamic character of the dependent variable.

\subsection{Basic Results}

Tables 1 and 2 present the results for the two dependent investment variables, Economic Affairs and Redistribution. It also includes results for several simplified equations to assure that the selection of controls does not drive the results. The tables show that with first-order autocorrelation coefficients between 0.3 and 0.7 , the dependent variables are highly auto-correlated and persistent.

\section{[Tables 1 and 2]}

Decentralisation (variable $T_{i t-1}$ ) has a significantly positive effect on infrastructure investment (Table 1), but not on investment in redistribution (Table 2). When expressed in \% changes, the parameter estimates for decentralisation imply that an increase in the sub-national tax share by one percentage point leads to an increase in investment in infrastructure of about 0.01 percentage points as share of GDP, or 1.7 percent evaluated at the sample mean.

Based on these results, it is possible to determine the long-run effect of decentralisation on investment in infrastructure. Indeed, Rodríguez-Pose (2010) shows that in a dynamic panel data regression the long-run effect of an independent variable can be derived by dividing its observed regression coefficient by the "speed of adjustment parameter”, which equals the parameter of the lagged dependent variable. In our case this suggests a long-term effect of decentralisation on infrastructure investment of $0.009 / 0.716=0.013$, or 2.5 percent for an increase in the sub-national tax share by one percentage point (evaluated at the sample mean). 
The variable $G_{i t}$ (capital transfers) has a significantly positive impact on economic affairs, transport infrastructure and redistribution. As to the interaction term between tax decentralisation and grants $\left(T_{i t-1} \times G_{i t}\right)$, it is significant only for economic affairs with a negative sign. This suggests that the impact of decentralisation on infrastructure investment is inversely related to the amount of investment grants received by regional governments. This result is not surprising if one sees investment grants as instrument of the centre to influence regional investment decisions. Investment grants taken alone put a monetary incentive for regions to invest. At the same time our results suggest that decentralisation taken alone also puts incentives for regions to invest (in infrastructure). Accordingly, by undermining the positive effect of decentralisation through the backdoor by providing conditional transfers weakens the positive link between decentralisation and regional investment in infrastructure.

With a significant interaction term, the overall effect of decentralisation has to be evaluated at a reasonable level of investment grants. Evaluated at the sample mean of investment grants, the effect of decentralisation on investment decreases from 0.009 to 0.006 but remains significant at the $1 \%$ level.

GDP and general government debt are insignificant in all of these specifications. At the same time, as the results in Column (4) demonstrate, their inclusion does not drive our main results. Omitting GDP and the fiscal variables in the model also addresses concerns that endogeneity may distort our results.

\subsection{Robustness Checks and Extensions of the Model}

To place our results in a broader perspective and check their robustness, this section discusses several extension of the basic model and presents results for regional transport investment only, investment in economic affairs by the central government and total regional investment. 
Data are available not only for economic affairs as aggregate investment, but also for regional transport investment as its main component. However, this information is only available for a subset of countries. Column (1) in Table 3 shows that as for regional investment in economic affairs, total decentralisation and investment grants have a significantly positive effect on regional transport investment; the interaction term is significantly negative. The effect size of decentralisation is about 60 percent higher than for economic affairs in total (Column (2), Table (3)). Note, however, that these results should be taken with a pinch of salt given the relatively small number of observations (132).

Decentralised spending responsibilities and more decision power for regions is not the same thing and may have different implications for regional investment. Additional spending responsibilities for regions result - by definition - in more spending. This in turn is likely to translate into higher regional investment. In contrast, more decision power of regions provides them with a much wider spectrum of actions. Regions may increase their spending overall, they may adjust the composition of their spending but leave the overall level unchanged or they may lower the level of total spending. ${ }^{8}$ To assure that the tax-decentralisation variable captures decentralisation that goes beyond the transfer of pure spending power, we also control for spending decentralisation. One might expect that (lagged) spending decentralisation and lagged regional investment are correlated. However, due to the different transformations applied (public investment relative to trend GDP versus regional expenditure as a share), the correlation between these two variables is low $(\rho=0.11)$. Column (2) in Table 3 shows that, when adding spending decentralisation to the model, the parameter of revenue decentralisation is smaller but remains significant for infrastructure investment; $G_{i t}$ continues to have a

\footnotetext{
${ }^{8}$ Given the definition of our principal measure of decentralisation (regional tax revenue/general government tax revenue) it also increased if regions were granted the right to levy taxes, but would not do so, for instance if it were in a tax competition with neighbouring regions.
} 
positive impact and the interaction term has a significantly negative impact on investment in economic affairs.

One might also argue that the degree of equalisation - the share of unconditional grants received by regional governments in their total revenues - affects decentralisation. But the results in Column (3) of Table (3) show that including equalisation, defined as the share of unconditional transfers over total transfers, has no impact on regional investment in economic affairs and does not alter the significance of our variables of interest.

To further corroborate our results on the link between regional investment and decentralisation, Column (4) of Table (5) displays results for central government investment in economic affairs. In contrast to the previous results, decentralisation has no impact on central government investment in infrastructure.

In separate regressions not reported in the tables, we also controlled for population and population growth, respectively. Thereby we take into account that investment may increase simply as a response to a growing population. Population is significant for investment in redistribution and population growth is significant for investment in infrastructure. The significance of $T_{i t-1}, G_{i t}$ and the interaction term, however, remains unchanged.

Changes in economic activities, which are not directly linked to decentralisation, may affect the regional tax share as well. For instance, a boom in the housing market would increase the local tax share if the local level relied more on this type of revenue. As it is difficult to control for such events, they may cause an endogeneity problem. The joint inclusion of population growth and GDP per capita should, however, absorb most of these effects and thus alleviate the problem. 
Regional governments may not simply receive investment grants for certain kinds of investment but rather apply for these grants. If this is the case, a potential omitted demand variable problem may dilute our results. To assure that the difficulties surrounding the $G_{i t}$ variable do not affect our interpretation of the results for the decentralisation variable, we also present estimation results for simplified models, which exclude $G_{i t}$ and/or the interaction term (Columns 2-3 in Tables 1 and 2). The parameter of tax decentralisation declines but remains significance at the $10 \%$ level.

Moreover, to address potential endogeneity of capital transfers and tax decentralisation as discussed in Section 3.3 we also show fixed effects and system GMM results as suggested by Soto (2010). When applying fixed effects OLS and using the cluster option, the significance of the variables of interest (decentralisation, investment grants and their interaction) remains unchanged. Only for the fixed effects model with cluster command, the decentralisation variable turns significant for regional investment in redistribution. As to system GMM results, Table A5 shows that we are able to reproduce our main results by using system GMM with a limited number of instruments. Note however, that debt is significantly positive for economic affairs and significantly negative for recreation. While $\operatorname{AR}(1)$ and $\operatorname{AR}(2)$ tests perform well, the Sargan test is mildly significant for "Economic Affairs". This problem can not be resolved with a restricted set of instrument variables. Overall, the Fixed Effects and system GMM results suggest that our findings are robust against the choice of estimation procedure.

\section{Conclusion}

As shown in the empirical analysis above, decentralisation in terms of tax shares increases public investment in infrastructure; public investment in redistribution is not 
significantly affected by decentralisation. Table (3) also includes results for total regional investment in Column (5). The positive link between total regional investment and decentralisation suggests that decentralisation on regional infrastructure investment is additional and does not go hand in hand with a considerable reduction in other types of regional investment, such as health, education or safety. This result confirms the finding by Välilä and Kappeler (2008) that decentralisation has a positive impact on overall infrastructure investment.

As to investment grants, they have a positive impact on both types of regional investment. The negative interaction between investment grants and decentralisation for regional infrastructure investment suggest that the impact of tax decentralisation on regional infrastructure investment declines with increasing receipts of investment grants by regional governments. This result is intuitive. As the significance of the taxdecentralisation parameter suggests, higher regional decision autonomy leads to more investment in infrastructure. Attempts to undermine the power of regions through the backdoor - e.g. by introducing conditional transfers - will at least partly offset the positive effect of decentralisation. This is not in contrast with the finding that investment grants per se, which are often provided contingent on investment, increase regional investment.

\section{References}

Alegre JG, Kappeler A, Kolev, A and Välilä T (2008) Composition of government investment in Europe: Some forensic evidence. EIB Papers 13/1: 23-54

Arellano M, Bond S (1991) Some tests of specification for panel data: Monte Carlo evidence and an application to employment equations. Review of Economics Studies 58, 277-297

Bel G and Fageda X (2009) Preventing competition because of solidarity: Rhetoric and reality of airport investments in Spain. Applied Economics 41(22): 2853-2865 
Benassy-Quere A, Gobalraja G and Trannoy A (2007) Tax and public input competition. Economic Policy

Bom P and Ligthart J (2009) How Productive is Public Capital? A Meta-Regression Analysis. Georgia State University, International Studies Program, Working Paper Series, at AYSPS, GSU paper0912

Borck R (2005) Fiscal competition, capital-skill complementarity, and the composition of public spending. German Institute for Economic Research Discussion Paper No. 504

Borck R, Caliendo M and Steiner V (2005) Fiscal competition and the composition of public spending: Theory and evidence. German Institute for Economic Research Discussion Paper No. 528

Brosio G and Ahmad E (2009) Does decentralization enhance service delivery and poverty reduction? Edward Elgar

Bruno GSF (2005) Estimation and inference in dynamic unbalanced panel data models with a small number of individuals. Working Paper 165, Centre Research on Innovation and Internationalization, Milan

Bucovetsky S (2005) Public Input Competition. Journal of Public Economics 89: 1763 $-1788$

Bucovetsky S and Smart M (2006) The Efficiency Consequences of Local Revenue Equalization: Tax Competition and Tax Distortions. Journal of Public Economic Theory 8(1): 119-144

Buettner T (2009) The contribution of equalization transfers to fiscal adjustment: Empirical results for German municipalities and a US-German comparison. Journal of Comparative Economics 37(3): 417-431

Buettner T and Wildasin D (2006) The dynamics of municipal fiscal adjustment. Journal of Public Economics 90(6-7): 1115-1132

Bun MJG and Kiviet JF (2003) On the diminishing returns of higher order terms in asymptotic expansions of bias. Economics Letters 79: 145-152

Careaga M and Weingast BR (2003) The fiscal pact with the devil: a positive approach to Fiscal Federalism, Revenue Sharing, and good governance. www.stanford.edu/ $\sim$ weingast/ careaga.weingast.ms2.pdf

Estache A and Sinha S (1995) Does decentralization increase spending on public infrastructure? The World Bank, Policy Research Working Paper Series 1457

Esteller A and Solé A (2005) Does decentralization improve the efficiency in the allocation of public investment? Evidence from Spain. Institut d'Economia de Barcelona (IEB), Working Papers 2005/5

Faguet J (2004): "Does decentralization increase government responsiveness to local needs?: Evidence from Bolivia," Journal of Public Economics 88(3-4): 867-893

Ferreira SG, Varsano R and Afonso JR (2005) Inter-jurisdictional fiscal competition: a review of the literature and policy recommendations. Rev Econ Polit 25/3: 295313

Garcia-Milà T and McGuire T (2001) Do Interregional Transfers Improve the Economic Performance of Poor Regions? The Case of Spain. International Tax and Public Finance 8(3), 281-296 
Hauptmeier S, Mittermaier F and Rincke J (2009): "Fiscal competition over taxes and public outputs: Theory and evidence,” ECB Working Paper No. 1033

Hindriks, J., Peralta, S. and Weber, S. (2008) Competing in taxes and investment under fiscal equalization. Journal of Public Economics 92(12): 2392-2402

Holtz-Eakin D and Schwartz AE (1995) Infrastructure in a structural model of economic growth. Regional Science and Urban Economics 25: 131-151

Hulten CR and Schwab RM (1997) A fiscal federalism approach to infrastructure policy. Regional Science and Urban Economics 27: 139-159

Im KS, Pesaran MH and Shin Y (1997) Testing for unit roots in heterogeneous panels. Unpublished paper, Department of Applied Economics, University of Cambridge.

Jin H, Qian Y and Weingast B (2005) Regional Decentralization and Fiscal Incentives: Federalism, Chinese Style. Journal of Public Economics 89(9-10): 1719-1742

Judson RA and Owen AL (1999) Estimating dynamic panel data models: a guide for macroeconomists. Economics Letters 65: 9-15

Kappeler A and Välilä T (2008) Fiscal federalism and the composition of public investment in Europe. European Journal of Political Economy 24: 562-570

Keen M and Marchand M (1997) Fiscal competition and the pattern of public spending. Journal of Public Economics 66(1): 33-53

Kiviet J F (1995): "On bias, inconsistency and efficiency of various estimators in dynamic panel data models,” Journal of Econometrics 68: 53-78

Lago-Peñas S (2006) Capital Grants and Regional Public Investment in Spain: Fungibility of Aid or Crowding-in Effect? Applied Economics 38 (15): 1737-1748

Maddala GS and Wu S (1997) A comparative study of unit root tests with panel data and a new simple test. Oxford Bulletin of Economics and Statistics 55: 631-652

Mehrotra A and Välilä T (2006) Public investment in Europe: evolution and determinants in perspective. Fiscal Studies 27/4: 443-471

Montolio D and Trillas F (2011) Regulatory federalism and industrial policy in broadband telecommunications. IEB Working Papers 2011/15, Institut d'Economia de Barcelona (IEB), Barcelona

Oates W (2005) Toward A Second-Generation Theory of Fiscal Federalism. International Tax and Public Finnce 12(4): 349-373

Oates W (1972): Fiscal Federalism. New York: Harcourt Brace Jovanovich

Primo D, Jacobsmeier M L and Milyo J (2007) Estimating the Impact of State Policies and Institutions with Mixed-Level Data. Politics and Policy Quarterly, 7/4: 446459

Puga D (1999) The rise and fall of regional inequalities. European Economic Review 43(2): 303-334

Rodríguez-Pose A (2010) Policy Trade and Regional Inequality. Research Working Paper 5347, The World Bank

Romp W and de Haan J (2005) Public capital and economic growth: a critical survey. EIB Papers, 13/1: 23-54

Seabright P (1996) Accountability and decentralisation in government: An incomplete contracts model. European Economic Review 40(1): 61-89

Sinn HW (2003): The new systems competition. Oxford, Basil Blackwell 
Solé-Ollé A and Sorribas-Navarro P (2011): The dynamic adjustment of local government budgets: does Spain behave differently? Applied Economics, forthcoming

Soto M (2010) System GMM with a small sample. Mimeo, Instituto de Análisis Económico, Barcelona.

Stegarescu D (2005) Public sector decentralization: measurement concepts and recent international trends. Fiscal Studies 26/3: 301-333

Sturm JE, Jacobs J and Groote P (1999): “Output effects of infrastructure investment in the Netherlands”, 1853-1913, Journal of Macroeconomics 21: 355-380

Välilä T Kosluz T and Mehrotra A (2005) Roads on a downhill: trends in EU infrastructure investment. EIB Papers, 18-40

Weingast B (2009) Second generation fiscal federalism: The implications of fiscal incentives. Journal of Urban Economics 65(3): 279-293

Zhuravskaya E (2000) Incentives to provide local public goods: fiscal federalism, Russian style. Journal of Public Economics 76: 337-368

Zodrow G and Mieszkowski P (1986) Pigou, Tiebout, property taxation, and the underprovision of local public goods. Journal of Urban Economics 19: 356-370

World Bank (2001) Decentralization and Governance: Does Decentralization Improve Public Service Delivery?. PREM Notes 55, Washington, D.C. 
Table 1:

Decentralization and Investment in Economic Affairs.

Corrected least squares dummy variable (LSDVC)

\begin{tabular}{|l|cccc|}
\hline & $(1)$ & $(2)$ & $(3)$ & $(4)$ \\
Lagged investment & $0.716^{* * *}$ & $0.739 * * *$ & $0.783^{* * *}$ & $0.724^{* * *}$ \\
& $(0.054)$ & $(0.056)$ & $(0.054)$ & $(0.054)$ \\
Capital grants & $0.009^{* * *}$ & $0.005^{* *}$ & $0.004^{*}$ & $0.009 * * *$ \\
& $(0.311)$ & $(0.002)$ & $(0.00203)$ & $(0.00296)$ \\
Capital grants $\times$ Tax decentralization $(t-1)$ & $0.168^{* * *}$ & $0.094^{* * *}$ & & $0.161^{* * *}$ \\
& $(0.045)$ & $(0.021)$ &.---- & $(0.039)$ \\
GDP(t-1) & $-0.400^{*}$ & & & $-0.397 * *$ \\
& $(0.207)$ &.---- &.---- & $(0.184)$ \\
Surplus(t-1) & 0.001 & 0.002 & 0.001 &.---- \\
Debt(t-1) & $(0-002)$ & $(0.002)$ & $(0.002)$ & \\
& -0.010 & -0.008 & 0.0032 &.---- \\
\hline Obs & $(0.012)$ & $(0.012)$ & $(0.013)$ & \\
No of countries & 0.001 & 0.001 & -0.001 &.---- \\
\hline
\end{tabular}

Notes: (1) ${ }^{* * *}:$ 1\% Significance Level, **: 5\% Significance Level,*: 10\% Significance Level. (2) System GMM estimator used to initialize the bias correction of xtlsdvc. (3) Year effects included.

Table 2:

Decentralization and Investment in Redistribution.

Corrected least squares dummy variable (LSDVC)

\begin{tabular}{|l|cccc|}
\hline & $(1)$ & $(2)$ & $(3)$ & $(4)$ \\
Lagged investment & $0.331^{* * *}$ & $0.342^{* * *}$ & $0.415^{* * *}$ & $0.356^{* * *}$ \\
& $(0.0398)$ & $(0.041)$ & $(0.046)$ & $(0.041)$ \\
Capital grants & 0.003 & -0.001 & -0.001 & 0.005 \\
& $(0.003)$ & $(0.002)$ & $(0.003)$ & $(0.003)$ \\
Capital grants $\times$ Tax decentralization(t-1) 1$)$ & -0.354 &..--- &.---- & $-0.408^{*}$ \\
GDP(t-1) & $0.201^{* * *}$ & $0.136^{* * *}$ &.--- & $0.217^{* * *}$ \\
& $(0.0513)$ & $(0.025)$ & & $(0.221)$ \\
Surplus(t-1) & 0.001 & 0.002 & 0.001 &.---- \\
Debt $(t-1)$ & $(0.002)$ & $(0.003)$ & $(0.003)$ & \\
& -0.010 & -0.008 & 0.007 &.---- \\
Obs & $(0.015)$ & $(0.015)$ & $(0.017)$ & \\
No of countries & -0.001 & -0.001 & -0.003 &.---- \\
\hline
\end{tabular}

Note: See Table 1. 
Table 3:

Decentralization and Investment. Additional results.

Corrected least squares dummy variable (LSDVC)

\begin{tabular}{|c|c|c|c|c|c|}
\hline & Transport & $\begin{array}{l}\text { Economic } \\
\text { Affairs }\end{array}$ & $\begin{array}{l}\text { Economic } \\
\text { Affairs }\end{array}$ & $\begin{array}{l}\quad \text { (4) } \\
\text { Cent. } \\
\text { Gov. } \\
\text { Ec. } \\
\text { Affairs }\end{array}$ & $\begin{array}{l}\text { Total } \\
\text { Investment }\end{array}$ \\
\hline Lagged investment & $\begin{array}{c}0.718^{* * *} \\
(0.0800)\end{array}$ & $\begin{array}{c}0.708^{* * *} \\
(0.0537)\end{array}$ & $\begin{array}{c}0.705^{* * *} \\
(0.0557)\end{array}$ & $\begin{array}{c}0.707^{* * *} \\
(0.0556)\end{array}$ & $\begin{array}{c}0.545 \\
(0.043)\end{array}$ \\
\hline Tax decentralization(t-1) & $\begin{array}{c}0.015^{* * * *} \\
(0.005)\end{array}$ & $\begin{array}{c}0.007 * * \\
(0.003)\end{array}$ & $\begin{array}{c}0.009 * * * \\
(0.003)\end{array}$ & $\begin{array}{c}0.009 \\
(0.007)\end{array}$ & $\begin{array}{c}0.014 \\
(0.007)\end{array}$ \\
\hline Capital grants & $\begin{array}{c}0.228 * * * \\
(0.0628)\end{array}$ & $\begin{array}{c}0.180 * * * \\
(0.0439)\end{array}$ & $\begin{array}{c}0.166^{* * *} \\
(0.0441)\end{array}$ & $\begin{array}{c}0.219 \\
(0.0984)\end{array}$ & $\begin{array}{c}0.446 \\
(0.102)\end{array}$ \\
\hline Capital grants $\times$ Tax decentralization(t-1) & $\begin{array}{c}-0.844^{* * *} \\
(0.311)\end{array}$ & $\begin{array}{c}-0.418^{* *} \\
(0.204)\end{array}$ & $\begin{array}{l}-0.396 * \\
(0.206)\end{array}$ & $\begin{array}{l}-0.466 \\
(0.453)\end{array}$ & $\begin{array}{l}-0.595 \\
(0.469)\end{array}$ \\
\hline Spending decentralization(t-1) &.---- & $\begin{array}{c}0.006 * * * \\
(0.002)\end{array}$ &.---- & --.-- & ----- \\
\hline Equalization(t-1) & --.-- &.---- & $\begin{array}{c}0.001 \\
(0.001)\end{array}$ & --.-- & --.-- \\
\hline$G D P(t-1)$ & $\begin{array}{c}-0.001 \\
(0.004)\end{array}$ & $\begin{array}{c}0.001 \\
(0.002)\end{array}$ & $\begin{array}{c}0.001 \\
(0.002)\end{array}$ & $\begin{array}{c}-0.003 \\
(0.005)\end{array}$ & $\begin{array}{c}0.006 \\
(0.005)\end{array}$ \\
\hline Surplus(t-1) & $\begin{array}{c}-0.002 \\
(0.0268)\end{array}$ & $\begin{array}{c}-0.009 \\
(0.0123)\end{array}$ & $\begin{array}{c}-0.011 \\
(0.0124)\end{array}$ & $\begin{array}{c}-0.080^{* * *} \\
(0.0273)\end{array}$ & $\begin{array}{c}-0.029 \\
(0.02937)\end{array}$ \\
\hline $\operatorname{Debt}(t-1)$ & $\begin{array}{c}0.001 \\
(0.002)\end{array}$ & $\begin{array}{c}0.001 \\
(0.001)\end{array}$ & $\begin{array}{c}0.001 \\
(0.001)\end{array}$ & $\begin{array}{l}-0.002 \\
(0.002)\end{array}$ & $\begin{array}{l}-0.001 \\
(0.002)\end{array}$ \\
\hline Obs & 132 & 281 & 281 & 281 & 281 \\
\hline No of countries & 11 & 20 & 20 & 20 & 20 \\
\hline
\end{tabular}

Note: See Table 1. 


\section{Annex:}

Figure A.1:

Shares of central and other levels of government in aggregate government investment (averages, 2000-05)

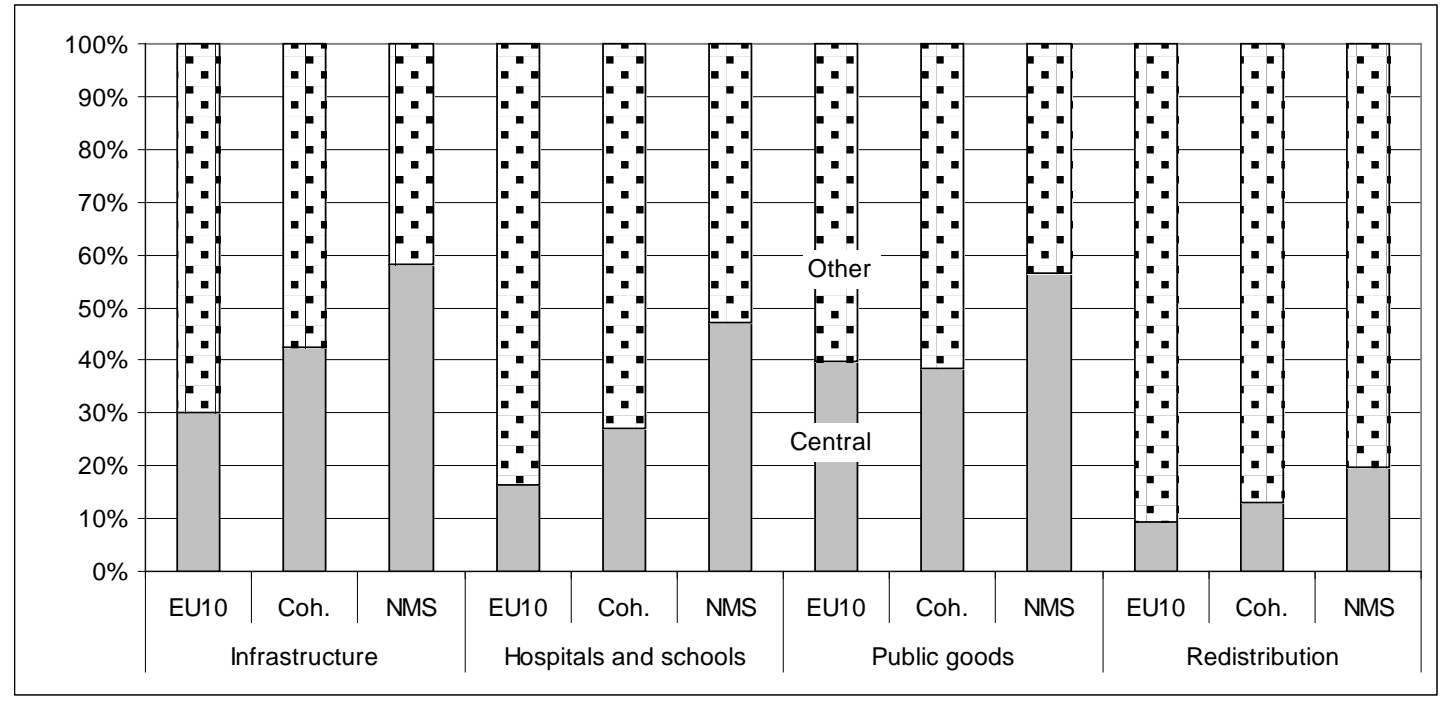

Source: Alegre et al. (2008)

Notes: (1) EU-10 comprises all old EU-15 member states excluding LU and the Cohesion countries ("Coh." in the graph, including Greece, Ireland, Portugal, Spain). NMS denotes new member states.

(2) Classification of government investment follows Alegre et al. (2008).

Table A1:

Descriptive Statistics of Variables

\begin{tabular}{|l|rrrrc|}
\hline \multicolumn{1}{|c|}{ Variable } & Obs & Mean & Std. Dev. & \multicolumn{1}{c|}{ Min } & Max \\
\hline Economic Affairs investment & 317 & 0.00525 & 0.00294 & 0.00021 & 0.01415 \\
Transport Infrastructure investment & 150 & 0.00489 & 0.00322 & 0.00010 & 0.01368 \\
Redistribution Investment & 317 & 0.00445 & 0.00294 & -0.01786 & 0.01695 \\
Tax decentralization(t-1) & 315 & 0.18636 & 0.13518 & 0.01152 & 0.52152 \\
Capital grants & 351 & 0.00799 & 0.00745 & 0.00047 & 0.06169 \\
Capital grants $\times$ Tax decentralization(t-1) & 313 & 0.00133 & 0.00165 & 0.00004 & 0.01123 \\
GDP(t-1) & 337 & 20634.0 & 10829.5 & 2856.0 & 61225.3 \\
Surplus(t-1) & 336 & -0.00157 & 0.00550 & -0.03319 & 0.02511 \\
Debt(t-1) & 344 & 0.57800 & 0.28178 & 0.04251 & 1.34174 \\
Spending decentralization(t-1) & 336 & 0.30133 & 0.13218 & 0.04325 & 0.65899 \\
Equalization(t-1) & 362 & 0.48944 & 0.16534 & 0.17278 & 0.83361 \\
\hline
\end{tabular}


Table A2:

Panel unit root tests.

\begin{tabular}{|lcc|}
\hline & \multicolumn{2}{c|}{ Fisher tests } \\
& Statistic & $P$-value \\
\hline Economic Affairs investment & 75.45 & 0.0006 \\
Redistribution Investment & 200.01 & 0 \\
Tax decentralization(t-1) & 66.54 & 0.0053 \\
Capital grants & 143.91 & 0 \\
GDP(t-1) & 54.33 & 0.0648 \\
Surplus(t-1) & 106.17 & 0 \\
Debt(t-1) & 89.05 & 0 \\
Decentralisation expenditures(t-1) & 59.09 & 0.0263 \\
Equalisation(t-1) & 111.91 & 0 \\
\hline
\end{tabular}

Table A3:

Correlation among explanatory variables

\begin{tabular}{|l|ccccc|}
\hline & Tax dec $(t-1)$ & Capital grants & GDP(t-1) & Surplus(t-1) & Debt $(t-1)$ \\
\hline Tax decentralization(t-1) & 1 &.---- &.---- &.---- &.---- \\
Capital grants & -0.161 & 1 &.---- &.---- &.---- \\
GDP $(t-1)$ & -0.035 & -0.024 & 1 &.---- &.---- \\
Surplus $(t-1)$ & -0.167 & -0.098 & 0.044 & 1 &.---- \\
Debt $(t-1)$ & -0.058 & -0.041 & -0.115 & -0.109 & 1 \\
\hline
\end{tabular}

Table A4:

Autocorrelation of Dependent Variables

\begin{tabular}{|l|ccc|}
\hline & $A C$ & Q-Stat & Prob \\
\hline Economic Affairs investment & 0.884 & 249.98 & 0 \\
Redistribution Investment & 0.739 & 174.72 & 0 \\
\hline
\end{tabular}


Table A.5:

Decentralization and Investment in Redistribution

Results for Fixed Effects OLS with and without cluster option and System GMM

\begin{tabular}{|c|c|c|c|c|c|c|}
\hline & \multicolumn{3}{|c|}{ Economic Affairs } & \multicolumn{3}{|c|}{$\begin{array}{c}(5) \\
\text { Redistribution }\end{array}$} \\
\hline & $\begin{array}{c}F E \\
\text { (cluster) }\end{array}$ & $F E$ & System GMM & $\begin{array}{c}F E \\
\text { (cluster) }\end{array}$ & $F E$ & $\begin{array}{c}\text { System } \\
\text { GMM }\end{array}$ \\
\hline Lagged investment &.---- & $\begin{array}{c}0.555^{* * *} \\
(-0.05)\end{array}$ & $\begin{array}{c}0.872^{* * *} \\
(0.967)\end{array}$ &.---- & $\begin{array}{r}0.279 * * * \\
(-0.036)\end{array}$ & $\begin{array}{c}0.448 * * * \\
(0.105)\end{array}$ \\
\hline Tax decentralization(t-1) & $\begin{array}{l}0.017 * * \\
(-0.006)\end{array}$ & $\begin{array}{c}0.010^{* * *} \\
(-0.002)\end{array}$ & $\begin{array}{l}0.012^{*} \\
(0.007)\end{array}$ & $\begin{array}{c}0.006 \\
(-0.004)\end{array}$ & $\begin{array}{c}0.004 \\
(-0.003)\end{array}$ & $\begin{array}{c}0.004 \\
(0.006)\end{array}$ \\
\hline Capital grants & $\begin{array}{l}0.247^{* * *} \\
(0.083)^{*}\end{array}$ & $\begin{array}{c}0.165^{* * *} \\
(-0.034)\end{array}$ & $\begin{array}{l}0.278^{* *} \\
(0.123)\end{array}$ & $\begin{array}{l}0.259 * * \\
(-0.098)\end{array}$ & $\begin{array}{r}0.208^{* * * *} \\
(-0.037)\end{array}$ & $\begin{array}{l}0.194^{* *} \\
(0.091)\end{array}$ \\
\hline $\begin{array}{l}\text { Capital grants } \times \text { Tax } \\
\text { decentralization }(t-1)\end{array}$ & $\begin{array}{c}-0.723 \\
(-0.442)\end{array}$ & $\begin{array}{l}-0.42 * * \\
(-0.161)\end{array}$ & $\begin{array}{l}-0.986 * \\
(0.533)\end{array}$ & $\begin{array}{l}-0.506 \\
(-0.39)\end{array}$ & $\begin{array}{r}-0.370^{* *} \\
(-0.176)\end{array}$ & $\begin{array}{l}-0.192 \\
(0.437)\end{array}$ \\
\hline$G D P(t-1)$ & $\begin{array}{c}0.002 \\
(-0.006)\end{array}$ & $\begin{array}{c}0.001 \\
(-0.002)\end{array}$ & $\begin{array}{l}-0.002 \\
(0.013)\end{array}$ & $\begin{array}{l}-0.002 \\
(-0.006)\end{array}$ & $\begin{array}{c}0.004 \\
(-0.002)\end{array}$ & $\begin{array}{c}-0.004 \\
(0.1)\end{array}$ \\
\hline $\begin{array}{l}\text { Surplus(t-1) } \\
\operatorname{Debt}(t-1)\end{array}$ & $\begin{array}{c}-0.035^{* *} \\
(-0.011) \\
-0.002^{* *} \\
(-0.001)\end{array}$ & $\begin{array}{c}-0.013 \\
(-0.011) \\
0.001 \\
(0.001)\end{array}$ & $\begin{array}{c}0.000 \\
(0.000) \\
0.001^{*} \\
(0.000)\end{array}$ & $\begin{array}{c}-0.030^{* *} \\
(-0.011) \\
-0.003^{* *} \\
(-0.001)\end{array}$ & $\begin{array}{c}-0.011 \\
(-0.012) \\
-0.002 * * \\
(-0.001)\end{array}$ & $\begin{array}{c}0.008 \\
(0.013) \\
-0.001^{* * *} \\
(0.000)\end{array}$ \\
\hline Obs & 284 & 284 & 281 & 284 & 284 & 281 \\
\hline No of countries & 11 & 20 & 20 & 20 & 20 & 20 \\
\hline No of instruments & & & 16 & & & 16 \\
\hline Sargan & & & 0.099 & & & 0.459 \\
\hline$A R(1)$ & & & 0 & & & 0.002 \\
\hline$A R(2)$ & & & 0.173 & & & 0.477 \\
\hline
\end{tabular}

Notes: (1) ***: 1\% Significance Level, **: 5\% Significance Level,*: 10\% Significance Level. Pvalues reported for AR(1), AR(2) and Sargan tests. 